\title{
Violence as development? A challenge to the church
}

\author{
Author: \\ Christina Landman ${ }^{1}$ \\ Affiliation: \\ ${ }^{1}$ Research Institute for \\ Theology and Religion, \\ University of South Africa, \\ South Africa \\ Correspondence to: \\ Christina Landman \\ Email: \\ landmc@unisa.ac.za \\ Postal address: \\ PO Box 14201, Lyttelton \\ 0140, South Africa \\ Dates: \\ Received: 25 July 2011 \\ Accepted: 27 Sept. 2011 \\ Published: 25 Nov. 2011 \\ How to cite this article: \\ Landman, C., 2011, 'Violence \\ as development? A challenge \\ to the church', Verbum et \\ Ecclesia 32(2), Art. \#577, \\ 6 pages. http://dx.doi. \\ org/10.4102/ve.v32i2.577
}

Dullstroom-Emnotweni was the site of protests against the lack of service delivery by local government in 2009. The local leadership of the Uniting Reformed Church in Southern Africa was confronted with challenges when its members got involved in acts of violence both from the side of the community and from the side of the police. Viewing itself as an asset to the community and an agent in its development towards health and wellbeing, the church was challenged by the situation in its prophetic capacity as well as in its relationship with the 'state'. In an attempt to negotiate answers to the church's relationship with the 'state' in situations of violence, the uprising in Dullstroom-Emnotweni is used as a case study, and Calvin's notion of the church as a world-transforming agent, the views of African women theologians on nonviolence, the practical piety of local religiousness, and the memory of systems of governance as 'evil' are used as intertexts to define the church's position vis-à-vis violence as an option for development. A position of caution is taken, a position in which the church retains both its political distance and its prophetic voice, remains true to its calling as an asset to community development, and condones violence cautiously when development is at stake.

\section{Introduction}

The aim of this article is to look at possible relationships between church and state, to define the church's pastoral and developmental role as an asset to civil society, and to apply this definition to dealing with a violent situation in a rural congregation where physical harm is done to people and property.

This threefold aim also determines the method and structure of the presentation. There is a short overview of historical views on the relationship between church and state. This overview will be based on published material. Secondly, the pastoral and developmental roles of the church as part of civil society will be described, using as sources John Calvin, practical piety, African women's theology in the words of Bernadette Mbuy-Beya, and the church as a 'religious health asset' as defined locally by Jim Cochrane. The reasons for using these seemingly unrelated sources as intertexts to come to a definition of church-state relationships in Dullstroom-Emnotweni will be explained with an analysis of the relevant sources. Finally, this definition of the church, which may include protest, will be tested against the experiences of a poor rural congregation in Dullstroom-Emnotweni where congregants have recently engaged in violent protests against the lack of service delivery by the local government.

\section{Views on the relationship between church and state}

In his preface to Christian political ethics, John Coleman (2008:ix-xvii) gives a useful overview of the two main streams of thought in Christian history on the relationship between church and 'state' vis-à-vis violence. One line of thought encourages Christians to be good citizens in the light of the call of Romans 13:1 to obey the government, and the admonition of 1 Peter 2:13 to accept the authority of all human institutions 'for the Lord's sake'. The other line of thought, of course, teaches that Christians should resist the 'state' (i.e. human authority) when there is a crisis of conscience. This is based on Acts 5:29 which urges Christians to 'obey God rather than men', as well as on the main thrust of the Book of Revelation which allows resistance to the 'state'.

Alongside these two lines of thought appear throughout history the binary notions of pacifism versus just war, that is, nonresistance versus violence. In an article entitled 'Nonresistance, defense, violence, and the Kingdom in Christian tradition', Lisa Sowle Cahill (1984:381ff) describes how thinking on the church's (non)violent relationship with the 'state' ranged from Tertullian who was a pacifist, to Augustine who all but conceived Christian just war theory, to Thomas Aquinas who justified war in terms of 'natural law', to Martin Luther who affirmed war but not individual self-defence, to Menno Simons and the Quakers who were radically pacifist, and eventually to 
John Calvin who warranted violence by civil authority in defence of the faith.

Calvin, of course, presupposed the sharing of interests between church and 'state' and therefore combined them in the struggle against onslaughts on this partnership. In his Institutes to the Christian Religion 4.20 he gave a clear answer to his unambiguous question:

If by the law of God all Christians are forbidden to kill, ... how can it be compatible with piety for magistrates to shed blood? But if we understand that ... the magistrate does not act at all from himself, but merely executes the judgments of God, we shall not be embarrassed with this scruple.

(Calvin transl. 1813:25)

And then he summarised and repeated himself even more clearly:

To hurt and to destroy are incompatible with the character of the godly; but to avenge the afflictions of the righteous at the command of God, is neither to hurt not to destroy.

(Calvin transl. 1813:25)

To jump from Calvin to apartheid South Africa is legitimate in the light of the strong 'Calvinist' support of apartheid which appeared especially after 1948 when the Nationalist Party took control of government. After that, a situation arose in South Africa where government and Afrikaans-speaking Reformed churches defended each other vehemently against onslaughts from liberation movements and theologies under the pretext of Calvin's vision for church-state cooperation.

During apartheid, then, resistance was expressed towards this cooperation between church and state that upheld an exclusivist racist regime and presumed to be Calvinist. The South African Council of Churches (SACC), for example, encouraged its member churches to engage in protest against the state. After the bombing of Khotso House, the SACC headquarters in Johannesburg on 31 August 1988, the SACC even allowed for this protest to become violent (see Landman 2011).

The reason why the South African Council of Churches is singled out from amongst masses of resistance agents is because they have recently - that is, on 08 June 2011 - issued a statement on protest and violence against the present government in South Africa, which is of significance for the focus of this essay. The Statement (South African Council of Churches 2011) was issued by the Central Committee of the SACC after their meeting on 07 and 08 June 2011 at the Lakeside Airport Lodge, on the theme 'Following the Way, standing for the Truth and seeking Life: SACC Reclaiming and Revitalising the Spirit of Christian Witness and Prophetic Ministry'.

In this statement the SACC claims to see the protest of people against the 'failure of government to deliver basic services or to do so with regard for human rights and the dignity of citizens' as a 'cry of the people of South Africa' that needs to be heard by the church. The SACC, furthermore, is saddened that government used the police against the 'angry protesters instead of listening to people'. Criticising the use of violence by the state against the protesters, the SACC nevertheless includes in its strategy 'mobilising our members to protest' which, apparently, may include violence.

Having called for protest against the apartheid government, the SACC now sees no alternative other than to repeat the call for the protest of churches against a government that is viewed as riddled with corruption and nonservice delivery. Anti-apartheid protests inevitably turned violent, if not from the protesters' side, the reaction from the police was violent. And this brings the previously asked question to the table: has the relationship between church and state in South Africa become violent again? What does this 'violence' look like? And how should the church react to that in terms of a definition of what 'being church' should be like?

\section{The church as an asset to civil society}

The SACC statement calls for a definition of the church's role in South Africa today, as it relates to corruption on all levels of government, and their violent reaction to the people's protest. 'Violence' here, as elsewhere in this essay, refers to physical harm done against people and/or property.

Is the role of the church one of protest and reactionary violence? Or should it be one of pastoral and developmental concern? Or can it be both? Can protest that is viewed by government as violence be part of the task of the church to pastor and develop societies?

It is worth noting that history testifies to the fact that Christian thinkers have looked at the role of the church in society in binary ways. The one binary view is that the church should concern itself with spiritual matters only and, for the rest, teach Christians to be dutiful citizens, blend with culture, and even learn from the 'secular' (see Stackhouse, in Coleman 2008:54-66). The other binary situation is for the church to isolate itself from the 'world', to acknowledge the sovereignty of God above all, and not to allow the things of God to be contaminated by the things of Caesar (Troeltsch 1931). In the latter case, the church sees itself as a loose community of individual believers who are advised to flee into mysticism and soulism for their own salvation.

John Calvin might have been - albeit wrongly - used in defence of an apartheid church-state relationship that violently protected its exclusivist claim to power against a majority of society, but it may be time, here, to refer to his view on the formative role the church needs to play in the socio-political world. This, then, will be a third alternative to the binaries of the church's role vis-à-vis the world as one of either subordination or isolation. In an article, 'The concern of the church in the socio-political world: a Calvinist and Reformed perspective', Cornelius Plantinga (1983:191) quotes Calvin - in his Commentaries - to have said: 'Although Christ has already begun to set up the Kingdom of God, his death was the real beginning of a right order and the full restoration of the world'. Thus, Plantinga indicates 
(1983:203), that, 'as Calvinism spread out ... the idea of the church as agent in social transformation spread accordingly'. Consequently, it has become characteristic of a Reformed view that 'Christians in the church do not so much exist as co-exist' (Plantinga 1983:204).

Under theologians in South Africa, Calvinism has functioned mainly as a dogma and a political agenda. However, amongst the laity it was always mixed with a practical piety. And, as Dirkie Smit reminds us in his 'Views on Calvin's ethics from a South African perspective' (2009:7), in Calvin's thought, 'worship and justice, piety and righteousness belong together'. Yet, as a child, I remember that the 'piety part' of Calvin's thinking came into realisation amongst believers who were least exposed to dogmatic Calvinism. It was the women's organisations in the Dutch Reformed Church - the church hardest hit by apartheid Calvinism - that laboured relentlessly inside and outside congregations to help the poor and the homeless.

Calvin, then, has been wrongly quoted to support an unhealthy relationship between church and state in which the church - in this case the Dutch Reformed Church - lost its prophetic and critical voice towards government. Also, locally, Calvin has been insufficiently quoted in relation to the practical implications of the world-transforming power of the church. What will be taken from Calvin to define the role of the church in modern South Africa, then, is simply his notion that the church is God's particular area of work, and that government and society at large constitute God's general area of work, leaving the church engaged in society and government in practice and dialogue, yet protecting its prophetic and justice-seeking voice from being compromised.

Also, the piety of local Calvinists was not innocently practical, but was fed by the belief that sin was the immorality of the individual. Thus misery, such as war or poverty, was privatised and perceived as caused by the sins of the individual. Developmental issues, such as poverty amongst White people, were tackled by addressing the moralreligious lifeview of poor people. Furthermore, because of the privatisation of sin and evil, there was an inability to see systems, such as apartheid, as evil.

Calvin's view of the church as world-formative and worldtransformative, yet not of the world, then, will be used here as a source for defining the role of the church in a corrupt and violent world, as will the practice of local piety. Furthermore, institutions such as local government will be seen as capable of being immoral and in need of change.

For the purpose of this article, however, transformative Calvinism and practical piety need to be supplemented and modernised by two recent trends in theology, those of women's theologies and developmental theories. Here it will be done, firstly, by adding the voices of African women theologians and, secondly, by exploring the impact of recent research in the field of development on the role of religion as an asset in civil society. I introduce them here as sources adapted to defining the role of the church in present-day South Africa because of the influence they have exercised on my own thinking in this regard.

Being a member of the pan-African Circle of Concerned African Women Theologians, I have never encountered thoughts on retributive violence from any African woman theologian. The face of violence against women is explored and exposed, but reacting with violence against abuse is never considered. The work of the Congolese theologian, Bernadette Mbuy-Beya, published in her book Woman, who are you? A challenge (1998) is an example. This book contains a chapter entitled, 'Violence against the African woman' that was produced as a collaborative effort by the women of the Lubumbashi branch of the Circle mentioned earlier. In this document, the women speak of 'moral violence' which does not refer to types of violence that can be morally legitimised but which, quite the contrary, is violence that is inflicted in intimate spaces. Six of the manifestations of moral violence are identified, namely 'insults and offensive words, taboos and interdictions, infidelity, incest, summary repudiation, and refusal to allow (a woman) the custody of her children' (Mbuy-Beya 1998:63). The remedies for moral violence, however, are strictly nonviolent. They are, in short, education, reinstatement of moral values, protective laws, care, shelters, mother-daughter dialogue, cultural liberation, economic in(ter)dependence, and the creation of healthy leisure activities (Mbuy-Beya 1998:65-71). This view of African women theologians, then, is in juxtaposition to that of the South African Council of Churches and its call for mass action that may lead to violence on the part of the protesters, and is per se seen as violence by the police.

This brings us to development as a function of faith communities, or, the role of the church in society viewed as an asset to the community at large. Development has a six fold aim vis-à-vis communities that are in need of growth and health. This aim entails (1) securing health systems, (2) securing social systems, (3) establishing recreation facilities, (4) enhancing moral fabric, (5) stimulating entrepreneurshipand (6) protecting the environment (Van Niekerk 2008). Building on the view that religion is an asset to the community, the Spiritual and Religious Assets Project (SRAP) is developing theoretical programmes for religions to manage their community outreach with the aim of healing society. This project collaborates with the international African Religious Health Assets Programme (ARHAP), and is housed at the University of Cape Town under the directorship of Prof Jim Cochrane (2010). Religious health assets are described as 'locally embedded religious images, values, practices, people and organisations that might issue in action to heal' (Cochrane 2010:3). Too complicated to be reduced to a few sentences, this model empowers religions to develop both their tangible and intangible assets to enhance the health of communities. The tangible assets of a church will include, for instance, the use of its building(s) as a clinic or a crèche, or for training. Fellowships and women's organisations, choirs, rituals and funerals are part of the tangible assets of churches. Actually, the very presence of a church in the 
community, especially in rural and isolated communities, is an asset that heals. Intangible religious health assets include prayer, resilience, health-seeking behaviour, motivation, responsibility, commitment, and a sense of meaning and belonging. According to this model, the prophetic voice of the church would be one of its intangible assets, as would (be) physical and structural or political resistance.

This model is useful as a working definition of the role of the church in society and towards government because of the entitlement of churches to act as agents, instead of institutions, that specialise in praying for the miraculous. The model also allows for the prophetic and critical voice of the church, and even for the latter's managing of physical resistance to a failing government.

Although the model of religion as presenting religious health assets does not use concepts such as 'development' or 'pastoral care', it can be translated into these concepts. Today the pastoral care vision of the church entails creating a community of care, engaging in the development and health of the community, forming social support groups, and working hand in glove with NGOs and even local government.

In summary, then, the working definition of the church and its role vis-à-vis the violent service-delivery uprising in Dullstroom will be based on (1) Calvin's view that the church is an agent that forms and transforms society and government but, because of its 'prophetic voice', will never be identical to them; (2) the legacy of practical piety amongst local believers, albeit without the notion of sin as personal only; (3) the insights into nonviolent resistance by African women theologians and (4) the ARHAP's view that religion is an asset to society; and that its prophetic voice in combination with structural resistance can work towards the health of society.

In effect this means that:

- As an asset of the community, the church has a particular contribution to make in society and towards government (which is a translation of Calvin's view of the church as God's particular area of work, and government and society as God's general area of work).

- Christian leaders are not to buy into politics, but to speak out against injustices and failures in government (which is a manifestation of its 'prophetic voice').

- Governance may display features of immorality (which defies the privatisation of sin and evil).

- The Christian approach to society includes practically and piously getting involved in issues of health, education and development (to which the church contributes as an agent with specific assets).

- The relationship of the church with resistance and protest remains ambivalent as far as the possibility of violence is concerned.

What will be explored next are the dialogical spaces between the church organising mass protest against the state that may lead to violence, and the church siding uncompromisingly with nonviolence. This will be done by means of the following case study.

\section{Violently protesting against local government in Sakhelwe: A case study}

Dullstroom-Emnotweni is a small town in Mpumalanga, one of South Africa's most eastern provinces. Mpumalanga, which means 'the East' in Zulu, shares a border with Mozambique. Two hours' drive from Johannesburg, and situated halfway between Pretoria and the Kruger National Park, the (previously) White town of Dullstroom consists mainly of holiday homes and restaurants of which there are 28 situated next to the main road.

Like most towns in South Africa, Dullstroom-Emnotweni has White and Black histories which, apparently, only coincided in the early 20th century when Black and White shed each other's blood over the land. Local texts (Kroon 2010) claim that the territory was 'uninhabited' in the mid-19th century after the Ndebele Bakoni had fled before the invading armies of king Mizilikatzi, with neither the Zulus nor the Swazis wanting to settle in the area because it was too rocky and cold. The history of the Black occupation is still to be researched. I, found members of the Bakoni near Draaikraal, 40 kilometres northeast of Dullstroom, who claim continuous occupation of the area. In Dullstroom I could trace this history only as far back as the 1950s with the oldest grave in the cemetery of the Black township, Sakhelwe, being that that of Simon Nogwaja Mnisi. He is buried with his wife Sophie Nobulawu Mnisi, and his second wife, Gogolaza Intombi Yengqova. His grandson, Paulus Dingizulu Mnisi, is the leader elder of the Uniting Reformed Church of Southern Africa in Dullstroom (situated in Sakhelwe). At present the township houses people of Ndebele, Swati and Pedi descent, and Zulu is the language used in church. This may be because, in the local schools, Zulu was used as medium of educating Black children, with Ndebele and Swati becoming written languages only recently.

In May 1884 the first White settlers came to the area. They were Dutch immigrants brought by Wolterus Dull, who also hailed from the Netherlands and after whom the town was called when it was proclaimed in January 1892. The town was destroyed during the Second South African War (1899-1902) and rebuilt under the leadership of a local person, T.N.H. Janson. The NH Church (Nederduits Hervormde Kerk) which had been destroyed during the war was rebuilt in 1905. The building of the Dutch Reformed Church (Nederduits Gereformeerde Kerk) was inaugurated in 1920. Its Black sister church in Sakhelwe, the Uniting Reformed Church (previously known as the Dutch Reformed Church in Africa) has as yet no church building. On 15 May 2011, the first joint service between the White and Black churches was held in the building of the Dutch Reformed Church. Although this highlighted the enormous difference in economic status 
between Black and White in Dullstroom-Emnotweni, it is likely to be repeated.

Today, with the 'White' town nestling in between the hills next to trout dams, the township of Sakhelwe is situated on top of a hill just outside the main town. DullstroomEmnotweni is the highest town above sea level in South Africa. It is cold in winter, and misty and rainy in summer. The township on the hill is especially exposed to the freezing and wet weather conditions.

The (previously White) town of Dullstroom consists of 600 permanent residents and 353 houses, of which at present 50 are up for sale. They are luxury homes, used mainly as weekend homes and guest houses. The dwindling economy has forced people to place their holiday homes on the market. Dullstroom-Emnotweni has a 'candy floss' economy, that is, one that is mainly dependent on tourism. It is situated 200 kilometres from the busy city of Johannesburg and, during peak times, especially long weekends, 2000 tourists can be accommodated. Dullstroom-Emnotweni has 28 restaurants and hotels, 52 registered businesses in total.

Whilst (previously White) Dullstroom is known for its fireplaces, pubs and cosy restaurants, the approximately 10000 inhabitants of Sakhelwe suffer the privations of inadequate housing, living in 700 houses (an additional 400 RDP houses were built after the service delivery uprisings). The Uniting Reformed Church in Southern Africa mentioned earlier, although it has no church building, has a 'pastorie' (parsonage) in Sakhelwe. According to the cornerstone, it was built in 1984 with money from the 'Sendingvriende van Dullstroom' (friends of missionary work in Dullstroom). This church, of which I am the pastor, divides Sakhelwe into two wards and colloquially names them after the type of housing available. One of the wards is called 'Fourrooms'. The houses here were built when, in the 1980s, the 'lokasie' was forcefully removed from the valley to the hill to make place for the sewerage farm. Incidentally and tragically, these houses that comprise four rooms only and were built by the apartheid government, are the 'best' houses in the township. The other ward is named 'Fourwalls'. This is where the RDP houses are built, consisting solely of four walls with an inside tap and an outside toilet. Here we find three generations and up to 30 people living in a single four-roomed house. The four-walled houses were built after the recent service-delivery uprisings. The approximately 400 RDP houses built here do not have electricity or water. There are no roads. An unknown number of these houses were allegedly allocated to council members, friends and family.

Against this background, what follows is a case study describing the violent protests of the youth of Sakhelwe against the local government about service-delivery issues, and the decisions that had to be made regarding the involvement of the church in violence against the 'state'.

The first role players in this case study are the youth of Sakhelwe. In May 2009 hundreds of youth in Sakhelwe participated in uprisings to protest against inadequate service delivery, uprisings that started in nearby Belfast and swept over Mpumalanga. The main issue was housing. According to a recent survey conducted by URCSA under my leadership, more than half of the youth in Sakhelwe between the ages of 18 and 35 have matriculated, but $90 \%$ are unemployed. They are living with their parents and grandparents in the small four-roomed houses mentioned earlier. The uprisers accused the councilors of the local municipality of dishing out RDP houses, that is, government-funded houses, to their friends and family - houses which, at that stage, had not yet even been built. In return, the ANC-dominated council pointed to aspiring councilors as the troublemakers who supplied the youth with liquor and incited them. The protests became violent and private property in town was damaged. The police moved in as the secondary role players in the case study, and fired rubber bullets at the protesters.

The third group of role players now appeared. This group consisted of me, as the pastor of URCSA, and the elders of this church. I strongly felt that the youth (several of whom were members of this church) who had been shot at and imprisoned, should be visited by the church. The aim was neither to reprimand nor to encourage them, but to carry out the Biblical command to visit the poor, the sick, the afflicted and those in prison. However, in this endeavour, resistance to joining me came from the church council. Some of the members of the church council were in the police force who, on command, had shot at the youngsters. Others were members of the local council who were accused of nepotism, and yet others who were accused of plying the youth with liquor and inciting them to revolt to gain votes for the coming council elections. Others simply thought that the church should not interfere in political action. When I proposed that we, as a church council, should discuss our engagement vis-à-vis the uprising, members felt that the protests were a matter apart from the church, and that they were not obliged to declare their participation in nor did they have to declare themselves against the uprisings.

In the end, the visits did take place - much to the embarrassment of almost all involved, youth as well as elders.

However, the church did get involved when the leading political party, as the fourth role player in the case study, called the church leaders of Sakhelwe to a meeting. There are several other churches in Sakhelwe, including the Lutheran and at least three independent churches, as well as a variety of individuals trying to establish new churches. At this meeting the church leaders were asked to preach peace and to tell their members not to engage in (violent) protests.

I protested against this because I saw it as the 'cooptation of the church by the state'. I agreed to preach on behalf of a liquor-free Sakhelwe. I also agreed to encourage my congregation to participate in a communal prayer meeting for Sakhelwe, although there was a strong suspicion that this meeting was going to be used by some to show their skills as 
preachers and to start a new church. But I had no intention of preaching nonviolence in favour of a specific political party.

The fifth party in this case study was made up of the affluent individuals in Dullstroom-Emnotweni, whose property had been damaged. They threatened to withdraw their support for URCSA in the township if the pastor did not 'call her congregation to order'.

It then became imperative to rethink the role of the church vis-à-vis the violence of its own members in protesting their views and needs, and the violent reaction of (local) government against this.

\section{Violence as development in the relationship between church and state: Conclusion}

Can development, seen as the empowerment of a community to transform itself towards health and wellbeing, be enhanced through violent protest? Can the church be part of this development in terms of a Calvinist ethic of 'world transformation' when violence is involved? Can the church, through its prophetic voice, that is in its call for justice in society, support violent reactions from the community against the lack of service delivery by local government? Or, on the other hand, should the church work hand in glove with the state to restore peace and order?

The case study described earlier, provides direction for answering these questions. During an interview with Mr Ignas Oberholzer, former chairperson of the ANC in the region and adviser to local government on servicedelivery issues, on 04 June 2011 he acknowledged that local government tended not to deliver unless forced to do so through protest action. However, a plan is now in motion to change the city council around, to identify the needs of rate payers (not only tax payers), and to establish a combined communication desk with them. 'In such a system there will be no place for uprisings and protest action', Oberholzer said after having revealed that members of Mkonto we Siswe, the 'military' wing of the ANC, had been sent in to oppress the previous uprisings by whatever means possible. The church, then, is to interpose itself in a constructive way between the extremes of violent protests and violent oppression. Where is this place?

This is a place from where the church contributes to the development of a community as a local and indigenous asset, without serving the party political aims of the government of the day. In effect, this would have invited the church to approve of protest action on the part of the community, were it not for the Calvinist notion that the church provides space for 'God's particular area of work' which equips the church with methods of community development that may show a preference for nonviolence in the light of recent insights, emanating especially from African women theologians that, in Christ, God has rejected violence as an option for change. However, in cases where violent protest is an option, the church takes on the challenge to side with the poor and deprived.

Furthermore, this is a place from which the church acknowledges that systems can be 'evil', that is, that governance can be corrupt, dysfunctional and failing to contribute to the development of the community in accordance with its mandate. Against unjust action from governance, the church speaks out prophetically, that is, voicing the protest of the community. When this voice needs to translate into supporting violent protests, the church is challenged to treat actions that can lead to the development of the community towards health and well-being, as a priority.

The church contributes specific societal assets, both tangible and intangible. It is the challenge of the church to decide when and how violent protest is essentially and effectually developmental.

\section{Author acknowledgements Competing interests}

The author declares that she has no financial or personal relationship(s) which may have inappropriately influenced her in writing this article.

\section{References}

Cahill, L.S., 1984, 'Nonresistance, defense, violence, and the Kingdom in Christian tradition', Interpretation, October, 380-397.

Calvin, J., 1813, Institutes of the Christian Relgion, vol. 2, transl. J. Allen, Westminster Press, Philadelphia, PA.

Cochrane, J., 2010, Spiritual and religious assets concepts: Religious health assets, spiritual capital, healthworlds, viewed 24 July 2001, from www.arhap.uct.ac.za

Coleman, J.A. (ed.), 2008, Christian political ethics, Princeton University Press, Princeton \& Oxford

Kroon, H. (ed.), 2010, Dullstroom Reader, 1-6, privately published.

Landman, C., 2011, The bombing of Kgotso House: An ecumenical perspective, viewed 24 July 2011, from www.christina-landman.co.za

Mbuy-Beya, B., 1998, Woman, who are you? A challenge, Paulines Publications, Limuru, Kenya.

Plantinga, C., 1983, 'The concern of the church in the socio-political world: A Calvinist and Reformed perspective', Calvin Theological Journal 18, November, 190-205.

Smit, D.J., 2009. 'Views on Calvin's ethics from a South African perspective', in R. Vosloo (ed.), Essays on being Reformed, pp. 1-28, Sun MeDIA, Stellenbosch.

South African Council of Churches, 2011, 'Central Committee Statement: Following the Way, standing for the Truth and seeking Life: SACC Reclaiming and Revitalising the Spirit of Christian Witness and Prophetic Ministry', Lakeside Airport Lodge, the Spirit of Christian Witness and Prophetic Ministry', Lakeside Airport Lodge
Johannesburg, 08th June 2011, viewed 24 July 2011, from www.sacc.org.za

Stackhouse, M.L., 2008, 'Christianity, civil society, and the state: A Protestant response', in J. Coleman (ed.), Christian political ethics, pp. 54-66, Princeton University Press, Princeton \& Oxford.

Troeltsch, E., 1931, The social teaching of the Christian churches, transl. O. Wyon, Macmillan, New York, NY

Van Niekerk, G., 2008, Workshop on development, Hoedspruit, South Africa, on 21 January 2008. 